\title{
Connecting Research to Action: A Useful Procedure
}

Dr. Jennifer A Turns, University of Washington

Dr. Brook Sattler, University of Washington

Dr. Kathryn Ann Mobrand, University of Washington

Drew Paine, Human Centered Design \& Engineering, University of Washington 


\section{Connecting Research to Action: A Useful Procedure}

\section{Introduction}

In recent years, the engineering education community has invested significant energy and resources in the creation of a rigorous empirical knowledge base to support the transformation of engineering education practice. For example, in the opening plenary at the 2011 American Society for Engineering Education (ASEE) Annual Conference, presenters focused on accelerating the use of research in practice. ${ }^{1}$ This investment has accelerated the need to ask questions such as the following: What are the implications for action of our research? What general ideas does our community have about how research can promote action? and What can be done to accelerate the rate at which research is used to transform engineering education? Such questions are part of the phenomenon known as translational work, or the work of connecting research to action. While such work has always been significant, dissatisfaction with the rate at which research drives action, as well as the belief that research can be more effectively leveraged to support action, has motivated increased activity around this topic. For example, the funding of large-scale centers on "translational science" and conference themes such as "knowing is not enough" are powerful indicators of the significance of the issue. Understanding and being able to engage in translational work is thus an important issue for emerging scholars.

Consider, as a public manifestation of translational work, formal research publications. Journal articles and conference papers often contain statements identifying implications for action. While there exists a large body of literature that focuses on the ways in which research articles are written $^{2,3}$, many of which focus on particular sections of research articles (e.g., abstracts ${ }^{4}$; introductions $^{5,6}$; discussions $s^{7,8}$ ), few scholars have written specifically about the ways in which implications for action are expressed within research articles. ${ }^{9}$ This gap in the literature makes it challenging for emerging scholars to learn effective ways to articulate the implications of their research publicly. Thus, it would be useful to have tools and procedures to help readers, including emerging scholars, more readily identify — and critically engage with — statements that researchers make that connect their research to action. In addition, these tools and procedures could foster discussions within the engineering education community about the most effective ways for authors to craft implications for action statements in order to engage readers and motivate action. In this paper, we introduce a procedure that we developed to do just that: help readers quickly identify, and critically engage with, statements researchers make about the implications of their work and, at the same time, encourage scholars to be more intentional about the ways in which they make visible the implications of their own research.

Core to our procedure is an effort to operationalize what counts as an "implication for action" in formal research publications. Heuristically, we focus on the idea that an implication for action sentence is a sentence that promotes a particular action being done. Consider the following examples:

- "We will continue to develop a toolbox of special graph designs to facilitate data exploration and analysis."

- "Ways of further amplifying and exploiting this advantage should be examined within the engineering curriculum."11 
- "It is important to prepare and familiarize students and raise their awareness of the challenging aspects of problem-based learning." 12

- "Further studies could also explore the effect of age and professional development on innovation capabilities, for example, by comparing freshman and senior undergraduates to advanced graduate students and professional engineers." 13

- "Juxtaposing these texts and highlighting their trade-offs can lead to a constructive discussion about the workings, functions, and limitations of academic engineering and its representational designs and practices." 14

These sentences are drawn from articles recently published in the Journal of Engineering Education (JEE). We assert that each of these sentences can be considered an "implication for action" sentence since each has a specific action that is being put forward: develop, examine, prepare and familiarize, explore, and juxtapose and highlight.

What differs across the five sentences is the specific way, or rhetorical strategy, that is used to indicate the importance of taking the action. For example, in the first example, the action (i.e., "develop a toolbox") is something that the authors themselves are planning to do (i.e., "we will continue"). The next three examples are similar to each other in that they all explicitly draw attention to the action being promoted, but they differ from each other in the level of assertiveness employed. Specifically, the assertiveness decreases from "should be" to "it is important to" to "could." In the final example, the action is not specifically suggested but, rather, linked to an outcome that is likely to be considered desirable.

Building upon the notion of an "implication for action" sentence, we developed a two-part procedure consisting of (1) identifying and coding implications for action sentences within a journal article and (2) analyzing the journal article based on the sentence-level coding. The first part of the procedure currently relies on five rhetorical strategies that correspond to the examples described above. The second part of the procedure involves using the results of the sentencelevel coding to characterize the journal article in terms of its implication for action sentences, think critically about the existing implication for action sentences (e.g., the appropriateness of the suggested actions, the findability of the sentences), and finally imagine new implications for action that may stem from the results but are not currently identified in the article.

In the next section, we provide additional background on translational work and translational discourse that motivated the development of our procedure. Next, we provide details on our twostep process (i.e., coding and characterizing). We then illustrate the procedure by applying it to three recently published articles from the Journal of Engineering Education.

We close by discussing the implications of our research for the engineering education community. Specifically, we focus on how emerging scholars can benefit from using our procedure to accelerate their growth as consumers and producers of research, and also on how the engineering education community could use the procedure to catalyze thinking about translational efforts in engineering education.

\section{Background}

In this section we situate our work through exploring the current state of translational work and describing the rhetorical foundations for the procedure we developed. 
Translational work

A main purpose of graduate education is to prepare scholars to be effective producers and consumers of research. A significant component of this preparation is scaffolding graduate students as they learn to make and articulate connections from research to action. As called for by Nyquist and Woodford, graduate students must have the capacity to connect their research to other research as well as to practice: "Leaders in business and industry argue that Ph.Ds. lack collaborative ways of thinking, intellectual and task-related, that are required in today's working world, and claim that students' dissertations and research interests are often disconnected from other knowledge and real-world problems" (p. 5). ${ }^{15}$

The work of making connections between research and practice is often described as translational work. Some disciplines approach translational work directly. For example, translational medicine is a growing subfield of medicine, as evidenced by new research centers and degree programs (e.g., The University of Edinburgh, UC San Francisco, UC Berkeley), and journals (e.g., the Journal of Translational Medicine). The aim of the Journal of Translational Medicine is to publish "articles focusing on information derived from human experimentation so as to optimise the communication between basic and clinical science."16

Attention to translational issues is also apparent in education. For example, the theme for the AERA 2013 meeting was "To know is not enough." The purpose of this theme was to draw attention to the importance of connecting research to action. In discussing the theme and highlights of the conference, Tyson and Ball noted "not all of our education constituencies know how we, as education researchers and as an organization, go about promoting 'the use of research to improve education and serve the public good." "17

While it appears that other disciplines have understood the importance of connecting research to action, in engineering and engineering education, this connection, while critical, has not received as much direct attention. Our work here is intended to help advance this issue within the engineering education community.

\section{Rhetorical foundations}

In developing our procedure, we were inspired by, and drew upon, the work of scholars - genre theorists, linguists, rhetoricians - who have systematically analyzed the rhetorical moves made within research publications. Their work highlights the importance of choices made regarding units of analysis, coding schemes, and interpretation schemes. For example, Connor examined variation in moves made in grant proposals, adapting Swales' communicative moves to come up with her definition of rhetorical move as "a functional unit, used for some identifiable rhetorical purpose" (p. 6). ${ }^{18}$ She defined ten rhetorical moves for grant proposals (e.g., gap, goals, means, benefits, competence claim, importance claim), many of which could be loosely mapped to the rhetorical moves we identified in our work. Bartunek and Rynes operationalized implications for practice in management journals using rhetorical strategies that were somewhat related to those we used in our work here. ${ }^{9}$ Crompton explored the rhetorical strategy of hedging as "an item of language which a speaker uses to explicitly qualify his/her lack of commitment to the truth of a proposition he/she utters (p. 281). ${ }^{19}$ Hyland, who also explored hedging, applied contextual analysis to results sections of biology reports, and asserted that hedging strategies can help writers "present statements with appropriate accuracy, caution, and humility" (p. 134) ${ }^{20}$

\section{A Procedure for Exploring How Implications are Handled in a Particular Journal Article}


In this section, we describe our procedure for examining how implications for action are handled within a single journal article. Specifically, we provide a procedure based on (a) identifying and coding implications for action sentences within a journal article, and (b) analyzing the journal article based on the sentence-level coding. Of note, this procedure was developed over a twoyear period, which involved several iterations: a submitted AERA paper, multiple on-campus presentations, a portion of a class based on the ideas here, and a published and presented FIE paper. $^{21}$ To date, we have not only developed the procedure, but also applied it to a corpus of 59 research articles from the Journal of Engineering Education (from Issue 2 of 2011 through Issue 1 of 2013, inclusive).

\section{Identifying and coding implications for action sentences within a journal article}

The procedure we developed begins with pulling all of the sentences from a research article, starting at the beginning of the discussion section and continuing through to the end of the article. We focus on these particular sections of the article because they are the sections most likely to have implications for action sentences since they summarize findings and conclusions from the paper. The sentences are placed in a spreadsheet for coding at the sentence level.

The first step in the coding process is to determine, for each sentence, whether it should be coded as an "implication for action" sentence — one that promotes a particular action. The second step in the coding process, which involves only those sentences that have been coded as "implications for action" sentences, is to identify constituent information (i.e., the action, whether the action is for research or practice, and the actor, if named).

As noted in the introduction, and reiterated in the previous paragraph, an implication for action sentence is one that promotes a particular action. The way in which authors promote actions varies in the level of pushiness, or assertiveness, employed-we use the term rhetorical strategy to characterize this "assertiveness spectrum." During the two-year period in which we have been engaged in this work, we have identified and named five rhetorical strategies based on a combination of syntactic and semantic cues (i.e., sentence structure and word choice). These rhetorical strategies are listed and defined below, in order of decreasing assertiveness, along with the corresponding examples from the corpus presented in the introduction.

Committed: Explicitly stating that an action has been taken or that there is a commitment to take the action.

- Example: "We will continue to develop a toolbox of special graph designs to facilitate data exploration and analysis." 10

Imperative: Explicitly stating that an action "should” be done

- Example: "Ways of further amplifying and exploiting this advantage should be examined within the engineering curriculum."11

Urged: Explicitly stating that it is important, urgent, necessary that an action be done

- Example: "It is important to prepare and familiarize students and raise their awareness of the challenging aspects of problem-based learning." 12

Possible: Explicitly stating that an action is possible, feasible, can/could be done

- Example: "Further studies could also explore the effect of age and professional development on innovation capabilities, for example, by comparing freshman and senior undergraduates to advanced graduate students and professional engineers.", 13

Outcome: Explicitly stating that an action that will lead to a particular outcome 
- Example: "Juxtaposing these texts and highlighting their trade-offs can lead to a constructive discussion about the workings, functions, and limitations of academic engineering and its representational designs and practices." 14

Continuing with the sentences that have been coded as implications for action and for which the particular rhetorical strategy has been identified, the next step is to record the constituent information: (a) the action being pushed, (b) whether the action pertains to research or practice, and (c) the actor who is supposed to take the action, indicating "not stated" if the actor is not identified. Of note, this procedure also offers an opportunity to characterize not only implications for practice, but also implications for research. The recording of constituent information for these example sentences is shown in Table 1.

\begin{tabular}{|c|c|c|c|c|}
\hline Sentence & $\begin{array}{c}\text { Rhetorical } \\
\text { Strategy }\end{array}$ & Action Pushed & $\begin{array}{c}\text { For } \\
\text { Research? }\end{array}$ & Actor \\
\hline $\begin{array}{l}\text { "We will continue to develop a toolbox of special } \\
\text { graph designs to facilitate data exploration and } \\
\text { analysis." }\end{array}$ & Committed & $\begin{array}{l}\text { develop a toolbox of } \\
\text { special graph designs }\end{array}$ & $\mathrm{Y}$ & The Authors \\
\hline $\begin{array}{l}\text { "Ways of further amplifying and exploiting this } \\
\text { advantage should be examined within the } \\
\text { engineering curriculum." }\end{array}$ & Imperative & (examine) ways to & $\mathrm{Y}$ & Not Stated \\
\hline $\begin{array}{l}\text { "It is important to prepare and familiarize } \\
\text { students and raise their awareness of the } \\
\text { challenging aspects of problem-based } \\
\text { learning.,"12 }\end{array}$ & Urged & $\begin{array}{l}\text { prepare and familiarize } \\
\text { students }\end{array}$ & $\mathrm{N}$ & Not Stated \\
\hline $\begin{array}{l}\text { "Further studies could also explore the effect of } \\
\text { age and professional development on innovation } \\
\text { capabilities, for example, by comparing freshman } \\
\text { and senior undergraduates to advanced graduate } \\
\text { students and professional engineers."13 }\end{array}$ & Possible & $\begin{array}{l}\text { explore the effect of age } \\
\text { and professional } \\
\text { development on } \\
\text { innovation capabilities }\end{array}$ & $\mathrm{Y}$ & Not Stated \\
\hline $\begin{array}{l}\text { "Juxtaposing these texts and highlighting their } \\
\text { trade-offs can lead to a constructive discussion } \\
\text { about the workings, functions, and limitations of } \\
\text { academic engineering and its representational } \\
\text { designs and practices."14 }\end{array}$ & Outcome & $\begin{array}{l}\text { (juxtapose and } \\
\text { highlight) the texts }\end{array}$ & $\mathrm{N}$ & Not Stated \\
\hline
\end{tabular}

Analyzing the journal article based on the sentence-level coding

The sentence-level coding provides a foundation for analyzing the ways in which implications for action are addressed in the article, at three levels: Characterize, Think Critically, and Imagine. For each of these levels of analysis, specific questions are explored:

Characterize: What does the article look like in terms of implications for action?

- Rhetorical strategy: How many sentences use each rhetorical strategy? How many total sentences were coded as implications for action? 
- Location: Where are the implications sentences located? How are they distributed relative to the non-implications sentences in our focal sections? How are they distributed throughout the focal sections that we analyzed?

- Action: What actions are being offered? Are there patterns in the types of actions being offered? Do the patterns in the types of actions being offered have any relationship to rhetorical strategy?

- Actors: Are actors identified in the implications sentences? If so, are there patterns in the types of actors being implicated? Do the patterns in the types of actors being implicated have any relationship to rhetorical strategy?

Think Critically: What happens when we think critically about implications for action in the article?

- Rhetorical strategy: Did the rhetorical strategies feel appropriately stated, given the actions?

- Location: Are the implications for action statements discoverable? Are they clustered together (so that they are likely to be discovered by the reader) or scattered?

- Action: Does the action stem from a finding? Is the action appropriately warranted from the finding(s) offered? Is the action realistic or concrete? For possibly ambiguous actions, are they elaborated in a way that makes them more actionable?

- Actors: Would the appropriate actor recognize that the authors are offering them an implication? Is the actor appropriately targeted and/or constrained, or is it generic?

Imagine: What implications for action can be imagined, but are not currently stated in the article?

- Rhetorical strategy: Could existing implications for action sentences be restated with a different rhetorical strategy? With what effect?

- Location: Could the sentences be made more discoverable?

- Action: What possible actions could be articulated that are related to the actual findings? Are there additional actions that would complement what was already said? If there were very large-scale actions offered, could more granular ideas be presented?

- Actors: Could more specific actors be addressed-and, if so, who?

These ideas are further unpacked in the next section, which illustrates the application of the procedure to three journal articles.

\section{Application of Procedure to Three Articles}

To elaborate and illustrate the application of our procedure, we chose three articles from our sample of $59 \mathrm{JEE}$ articles. Each article was chosen to illustrate one of three typical characterizations of implications for action sentences. The order of the articles is not significant and is not intended to make a statement about their relative effectiveness at expressing implications. The first article serves as an example of those articles in which the author explicitly calls out at least one section as offering implications. The second article serves as an example of those articles in which the author scatters the implications for action sentences throughout the sections we analyzed. Finally, the third article serves as an example of those articles in which the 
author does not offer any implications for practice, but offers only implications for further research. The complete set of coded sentences for each of the three example articles has been included in Appendices 1-3 as a reference for the reader.

In the visualizations we create as part of our procedure, each sentence that we extracted from the article becomes a data point that is plotted from left to right along the $\mathrm{x}$-axis, in the order of the appearance of that sentence in the article, with sentence number 1 placed at the origin. Those sentences that were not coded as implications for action sit on the $\mathrm{x}$-axis (see Fig. 1). Those sentences that were coded as implications for action are situated varying distances above the $\mathrm{x}$ axis relative to the assertiveness of their associated rhetorical strategy - the more assertive the strategy, the further above the x-axis the data point sits. As shown in the legend of Figure 1, sentences not coded as implications for action are represented as colored diamonds, sentences coded as implications for research are represented as colored squares, and sentences coded as implications for practice are represented as colored triangles. This visualization enables a reader to quickly assess the prevalence and distribution of implications statements within an article as well as the rhetorical strength of those statements. In other words, the reader can apprehend at a glance the various levels of assertiveness that author(s) use when making implications statements for research and practice and the patterns of the locations of those statements within the article.

Article I: Includes called-out implications sections

The authors of the first example article ${ }^{22}$ offer the reader specifically labeled sub-sections devoted to the implications of their work. The application of our procedure to Article I is depicted visually in Figure 1.

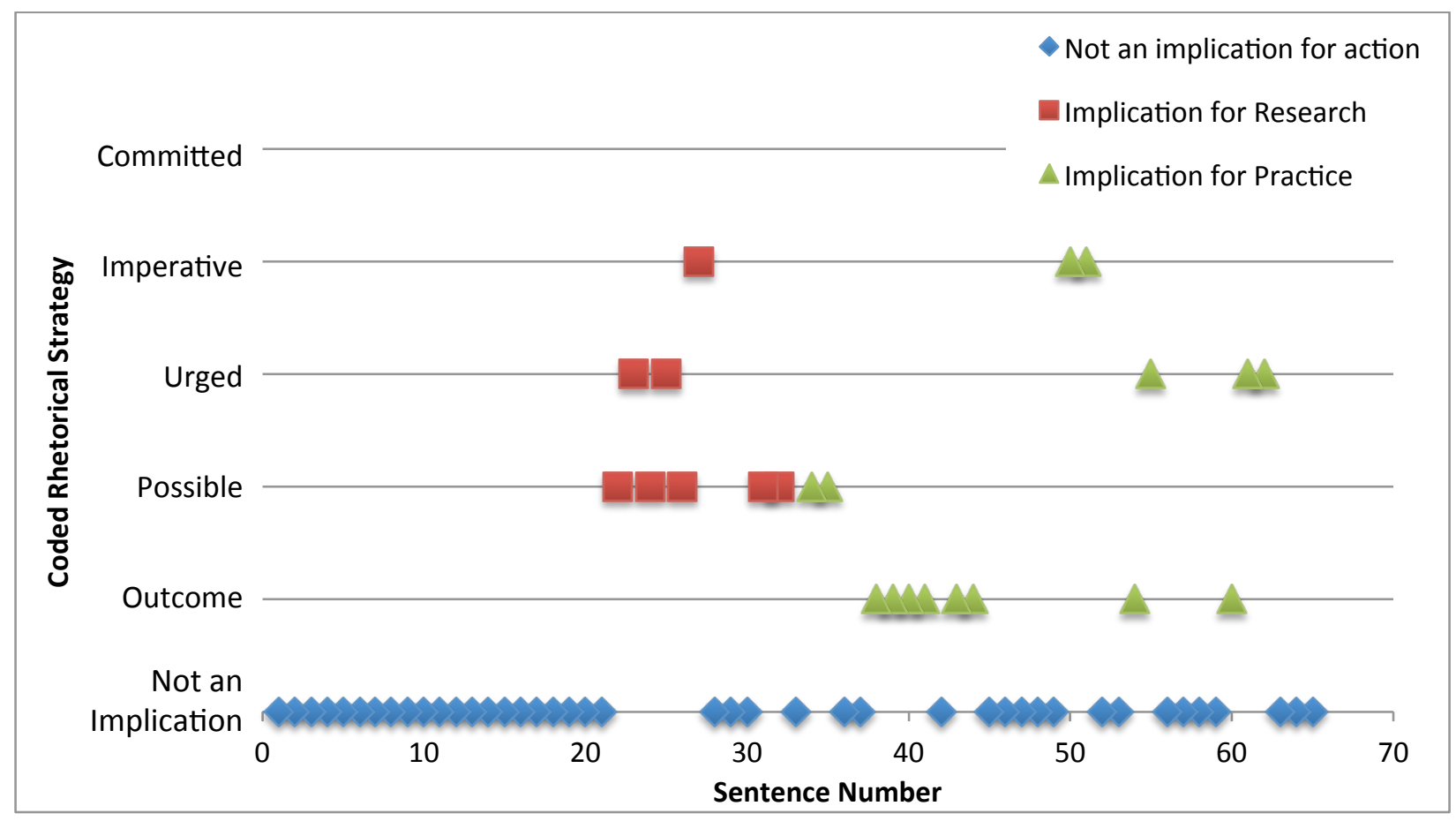

Figure 1. Location of sentences that were coded as implications for action within the analyzed text of Article I. The two prominent clusters of coded implications sentences, located roughly between sentences 20 and 30 and sentences 38-45, represent the two sub-sections of the article explicitly dedicated to implications. The coded implications sentences 
represent multiple rhetorical strategies. The blue diamonds on the $x$-axis represent those sentences from the analyzed text that were not coded as implications.

Characterize: Application of the procedure to Article I reveals 23 implications for action sentences, which span four of the five rhetorical strategies (see Fig. 1). Regarding location, as might be expected in an article that includes sub-sections devoted to implications, two distinct clusters of implications for action sentences are located toward the end of the "Discussion" section. The first cluster, which consists of implications for research (see red square markers in Fig. 1), occurs between sentences 20 and 30, which corresponds to a sub-section entitled "Implications for Future Research." Similarly, the second cluster, which consists of implications for practice (see green triangle markers in Fig. 1), occurs between sentences 38 and 45, which corresponds to a sub-section entitled "Implications for Teaching."

Application of the procedure also reveals that the actions being "pushed" in the implications sentences are either about further work (e.g., further research, additional studies, more studies on conceptions of engineering) or about views to be adopted or actions taken in practice (e.g., adopt a celebratory view, know the landscape of constructions, acquire a more sophisticated understanding, have students articulate ideas, make differences more transparent). With respect to actors, application of our procedure reveals that none of the eight implications for action sentences aimed at research explicitly name an actor; and, in addition, ten of the fifteen implications for action sentences aimed at practice have no specific actor named — rather, references are to "educators," "we," and information in a previous sentence.

Think Critically: Application of our procedure with respect to decisions about rhetorical strategies chosen by the authors reveals that the majority of the strategies used are not very "pushy." In other words, fewer than half of the implications for action statements (whether for research or practice) use rhetorical strategies that urge or direct readers to a path of action, with the majority of the statements being suggestions of possible actions or indications of possible outcomes should an action be taken (see Fig. 1). The location of implications for research or practice in this piece are readily discoverable as a result of the explicit sub-sections within the discussion that the authors have used to call explicit attention to the implications of their work. With respect to actions identified in the implications for practice sentences, many of the sentences offer a design-oriented activity; for example, creating things, or thinking about trying things. Finally, the actor being implicated in Article I is very general - researchers, educators at large. It is possible to infer that the educator being invoked is one who wishes to know the landscape of student constructions of engineering practice. Application of our procedure, which juxtaposes rhetorical strategy, actor, and action, provides opportunity to readily see, and critique, relationships; for example, the reader could think about the way in which the presence of an identified actor tends to lead to more specific actions.

Imagine: Application of our procedure affords the opportunity for readers to imagine ways in which strong rhetorical strategies (e.g., urged, imperative) may be used to more effectively push readers to action. Likewise, readers can imagine including sub-sections explicitly devoted to implications for research and/or practice to help readers find the implications statements, being aware that headings do not take the place of using strong rhetorical strategies. This analysis leaves the reader to contemplate whether the authors would have been well positioned to make much stronger implications statements, given their work. In addition, application of our procedure invites readers to imagine re-writing implications sentences to name more detailed 
actions (e.g., what actions could be articulated that are related to actual findings) and to call out specific actors (e.g., simply adding clauses to modify the use of the term, educator). In terms of actions in the implications for research sentences, the actions could be more concrete (e.g., not just future research or further studies on student conceptions).

Article II: Implications sentences are scattered throughout

The authors of the second example article ${ }^{23}$ offer the reader implications for action statements that are scattered throughout the sections of the article that we analyzed. The application of our procedure to Article II is depicted visually in Figure 2.

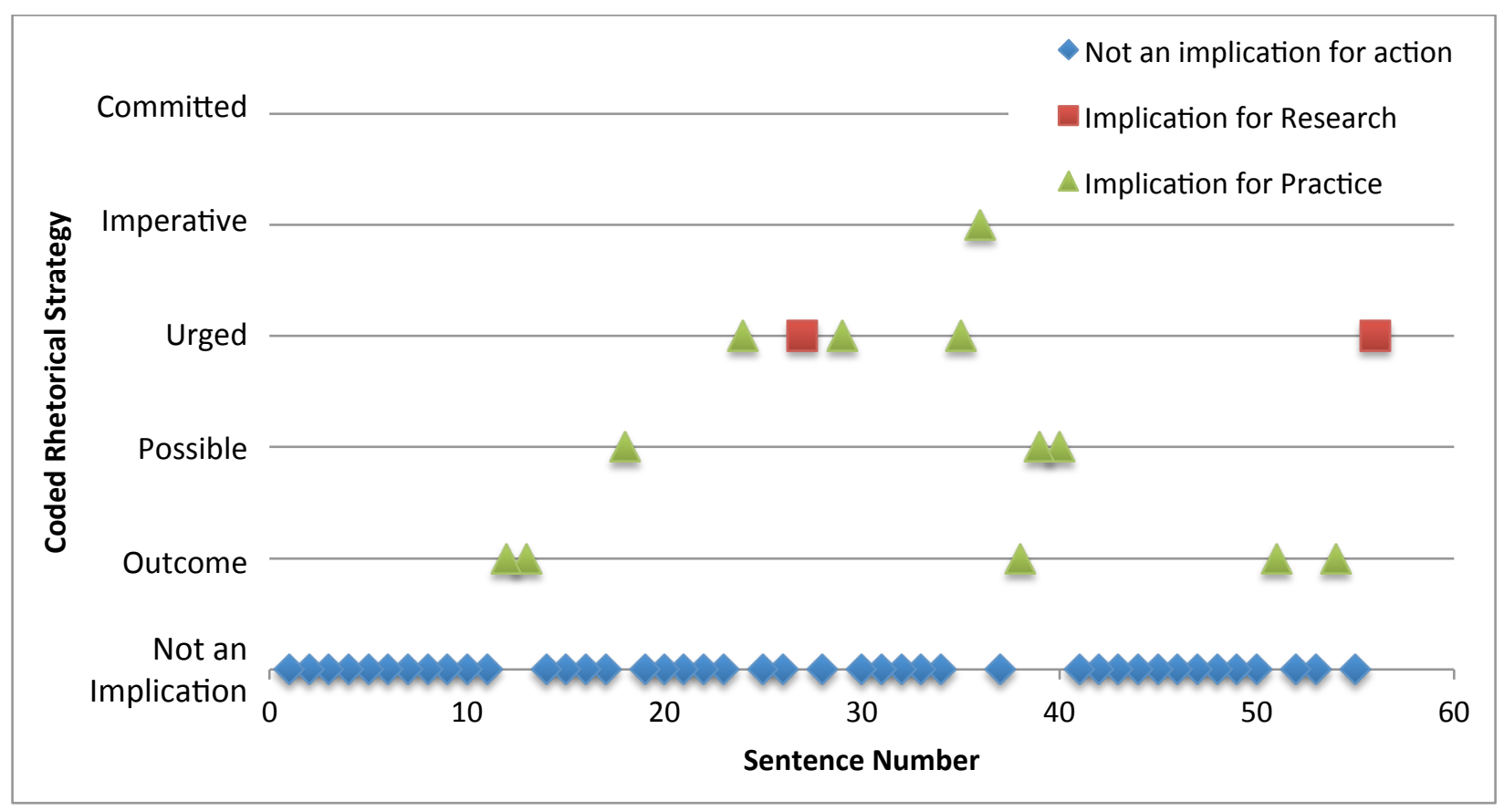

Figure 2. Location of sentences that were coded as implications for action within the analyzed text of Article II. The coded implications sentences represent multiple rhetorical strategies, and they are scattered throughout the text. The blue diamonds on the $x$-axis represent those sentences from the analyzed text that were not coded as implications.

Characterize: Application of our procedure to Article II reveals 14 implications for action sentences, spanning four of the five rhetorical strategies - as did the implications for action sentences in Article I. Unlike Article I, the location of the 14 implications sentences in Article II are scattered throughout the Discussion section. Two of these sentences are included in a bulleted list making them readily findable to a reader. This article does not include a sub-section that is explicitly titled, "implications," which means that locating the implications involves more work for the reader. The article does, however, include a sub-section titled, "Future Directions" that has a cluster of five implications for action sentences, with all five being for practice (as shown by the green triangles in Fig. 2, between sentences 35 and 40). In terms of actions, 12 of the 14 implications for action sentences in this article are for practice, and only 2 are for research; the research implications statements are very general in nature (e.g., conduct future research and do more work), and they do not identify an actor. With regard to the implications for practice, the actions include specific activities such as modeling interdisciplinarity, providing 
scaffolding, and working in teams. The actors identified include instructors, faculty, and students, which is a little more specific than the broader category, "educators."

Think Critically: As with Article I, application of our procedure to Article II reveals that most of the rhetorical strategies used are only slightly to moderately "pushy." Eight of the fourteen implications for action statements used either an Outcome or Possible rhetorical strategy. These eight statements may be less findable because the Outcome and Possible rhetorical strategies do not have the more easily identifiable, or "pushy," words that are used in the Urged and Imperative rhetorical strategies. Could the authors have used stronger, more visible, and more targeted implications statements in order to motivate readers to action? In terms of location, despite the authors' explicit sub-section titled "Future Directions" and the small clump of implications for action sentences within that section, the wide distribution of implications for action sentences more generally may make it difficult for readers to readily identify implications sentences. With respect to actions for research, through application of our procedure, the reader might consider, as with Article I, whether the authors may have missed opportunities to push the reader toward more specific actions. Regarding implications for action sentences that are aimed at practice, as noted above, the actions are a little more concrete, but the reader may consider that they could still be clearer. In addition, analysis of the actions with our procedure reveals that actions may be embedded within a particular way of thinking and, if the reader is already aligned with that way of thinking, he or she may be more receptive to the action being "pushed." With respect to actors, the actor is not stated in the implications for research sentences whereas the actor is identified generally, if at all, in the implications for practice sentences.

Imagine: Application of the procedure invites the reader to imagine ways that the implications for action sentences could be re-written using stronger rhetorical strategies; for example, those sentences using rhetorical strategies, "outcome" and "possible," might be re-written using an "urged" or "imperative" strategy. In addition, the reader could imagine crafting sections that are explicitly dedicated to implications as a way to not only make the implications easier to locate, but also help the author cluster the implications and, hence, tell a more compelling story. Application of the procedure also invites readers to imagine writing more detailed descriptions of actions and actors; for example, authors might describe specific ways in which instructors could scaffold team work or identify as actors faculty or instructors of certain types of courses.

Article III: Includes implications for research only

Finally, the authors of our third example article offer no implications for action sentences for practice - they offer actions only for research. ${ }^{24}$ The application of our procedure to Article III is depicted visually in Figure 3.

Characterize: Application of our procedure to Article III reveals 19 implications for action sentences, all of which are for research. The authors relied heavily upon the "urged" rhetorical strategy, which accounted for 11 of the 19 implications coded. The remaining 8 implications for action statements include the "outcome," "imperative," and "possible" rhetorical strategies (see Fig. 3). In terms of location, the implications for action for researchers are scattered throughout the paper's Discussion section, Conclusions, and Future Research and Limitations sections, with a cluster toward the end of the Conclusions. Application of our procedure reveals very specific actions being "pushed" in the implications sentences for research (e.g., modifying/evaluating survey elements, measuring teachers' perceptions, using validation techniques). Nearly all of the 
implications for research sentences had no identified actor; and, in the few cases that did, the actor was referred to generically as researchers.

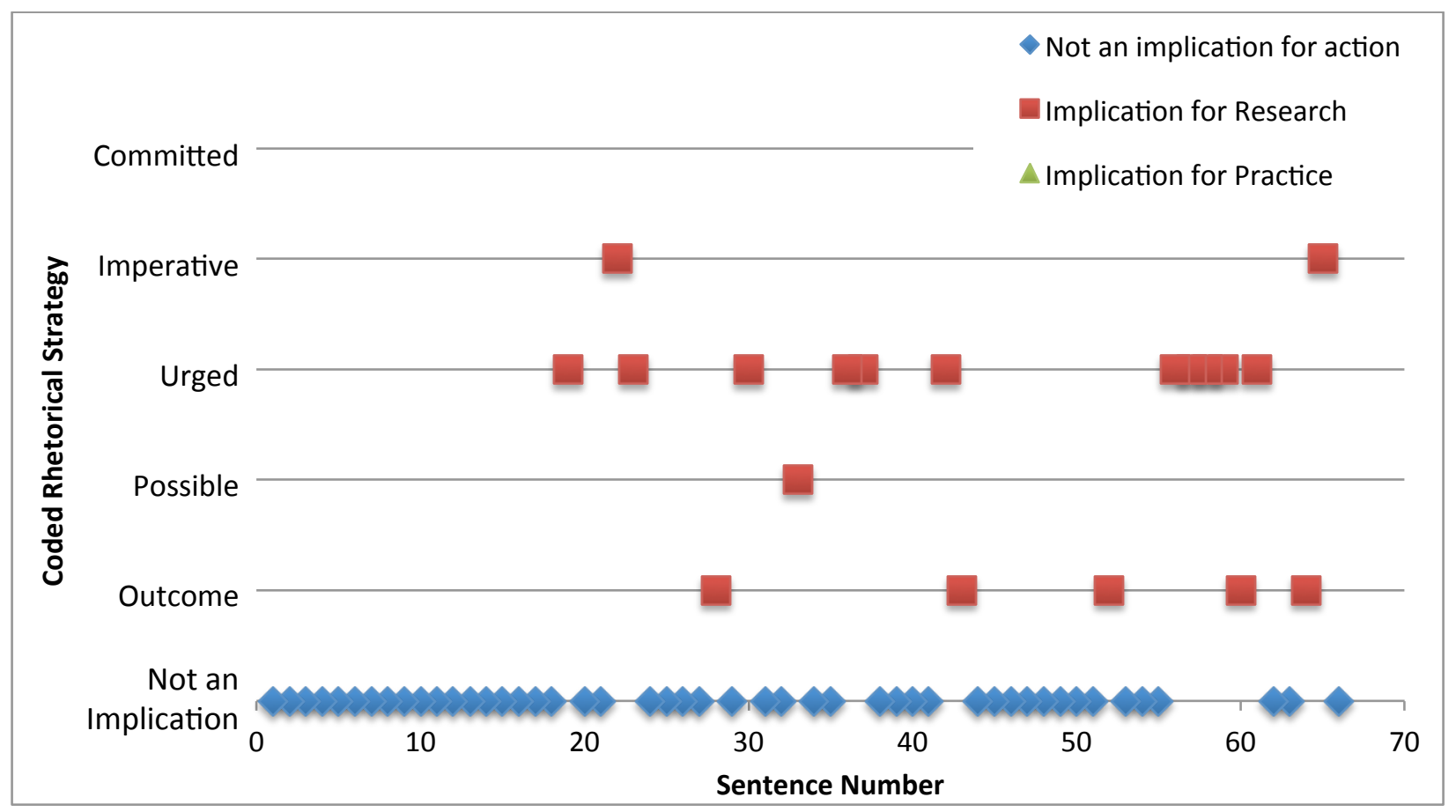

Figure 3. Location of sentences that were coded as implications for action within the analyzed text of Article III. The coded implications sentences represent multiple rhetorical strategies, and they are scattered throughout the text. The blue diamonds on the $x$-axis represent those sentences from the analyzed text that were not coded as implications. This article has implications sentences for research only.

Think Critically: Application of the procedure reveals that the majority (13 of 19) of implications for action sentences employ strong rhetorical strategies; however, the remaining six, which are "possible" and "outcome," might be made stronger. The reader might also think about why the authors do not use the "committed" rhetorical strategy — in an article with only research implications, it is often the case that the researchers also talk about what they are going to take on next (i.e., committing to). In terms of location, the implications for action sentences are scattered, reducing the reader's ability to find them. Our procedure also allows the reader to examine the various types of actions and the different levels of detail that authors use to describe actions (e.g., re-examine elements of the DET survey and potentially change these components). Because the implications for action in this article were all coded as implications for research, the reader can think about the effectiveness of letting the actor go unstated as the implied researcher versus making a more explicit statement about the actor as researcher.

Imagine: Application of our procedure offers the reader opportunity to imagine ways in which the implications for action sentences that employ somewhat weaker rhetorical strategies (e.g., "outcome," "possible") could be crafted using stronger rhetorical strategies. The reader might also imagine the researchers talking about their own plans to continue the research (i.e., using the "committed" rhetorical strategy). The reader might also imagine improving the location of implications by creating a sub-section for implications and by summarizing implications in bulleted lists to enhance findability. In terms of actions, through applying our procedure, readers could imagine implications for practice (e.g., building possible actions from 
the survey of teacher perceptions, evaluating interventions). With regard to actors, readers could envision specifying the particular type of researcher needed to make changes to this survey instrument-for example, should one of the original creators or a newer researcher potentially accomplish this work?

\section{Discussion and Caveats}

A key question driving this work was whether we could develop a procedure to use in identifying implications for action in published research. As previous sections have illustrated, we believe that we have developed a procedure that can reliably surface implications for action sentences. The procedure generates information about the various rhetorical strategies used by authors making implications statements, where the implications statements are located in the article and how dispersed they are, what actions are commonly called for by authors, what actors are identified, etc. The procedure scaffolds thinking about what is there, being critical of what is there, taking time to imagine what else could be there.

We readily acknowledge that the procedure we have developed has caveats that should be taken into account by anyone applying the procedure to a specific research article:

- Coding at the sentence level can create challenges when sentences include references to prior comments in an article. Moreover, coding at the sentence level may not reveal overall strategies for connecting research to action as well as coding at a larger unit of analysis, such as a paragraph.

- The five rhetorical strategies that we have identified may underrepresent the set of "implications for action" present in journal articles. While we have focused on five rhetorical strategies, across the period in which we have engaged in developing this procedure, we have come across other rhetorical strategies that could potentially be used to extend the set of strategies beyond five.

- Our procedure involves characterizing and analyzing what is written. While this procedure makes it possible to make inferences about what an author intended, such inferences about authors' intentions based on their writing should be made with caution. It is important to recognize that writers are not equally purposeful in their writing and thus may not be equally aware of their choices.

\section{Implications}

A key feature of this work is that we have developed a procedure that can provide information about the various ways in which implications for action are articulated in journal articles. We focus here on what can and should be done at this point. Specifically, we focus on the use of the procedure by emerging scholars and the engineering education community in general.

\section{How can reading journal articles using this procedure contribute to the development of} emerging scholars? Emerging scholars should consider applying this procedure to journal articles. There is ample reason to believe that by practicing such application of the procedure, emerging scholars will accelerate the development of their abilities to find implications for action, make connections between research and action (even when such connections are not present in the journal articles), and also write such implications statements in their own work. The reason to believe that such benefits will accrue lies in research on socialization to a field and disciplinary rhetoric. In general, scholars note that learning how to write in a discipline is a 
crucial step in the emerging scholar's socialization into their field-Russell suggests that it is a pathway to "taking on the identity, set of values, and, often, political stances of those who write in a particular discipline" (p. 258). ${ }^{25}$ Further, it is valuable to note that students learn disciplinary rhetoric in a reflective and intentional manner so that they may enter the conversation, making informed language choices and becoming thoughtful and proactive members of a disciplinary community. As Bazerman notes: "Explicit teaching of discourse holds what is taught up for inspection, provides the students with means to rethink the ends of the discourse, and offers a wider array of means to carry the discourse in new directions" (p. 76). ${ }^{26}$

\section{How can educators working with emerging scholars use our procedure to support emerging} scholars? We see an opportunity to study exactly how the use of the procedure helps emerging scholars. Such future work could involve creating testable propositions related to the idea that reading using this procedure will make emerging scholars more effective. In creating such testable propositions, scholarship on related phenomena (e.g., genre, discourse, rhetorical moves, and communicative moves) could be leveraged. In addition to supporting better reading, the propositions might go further: repeated use of the procedure to analyze the research articles of others can potentially enable an emerging scholar to more readily write the relevant sections in their own research articles. Such ability to write more effectively could result from insights gained through analyzing multiple articles. For example, we might conjecture that the opportunity to think critically about the findability of implications for action sentences (e.g., how is the findability related to rhetorical strategy, how is the findability related to location) will help emerging scholars produce research manuscripts where their own implications for action sentences are particularly findable.

\section{How can the procedure we have described be formally used to analyze a corpus of research articles from a particular discourse community in order to gain insight into the nature of translational discourse in that community? The engineering education community should leverage the procedure in order to stimulate conversation concerning translational work, to gain insight into the nature of translational work in engineering education. As noted before, we are currently engaged in such an analysis of articles published in the Journal of Engineering Education. Follow-on work could involve applying the procedure to other journals in engineering education, and then comparing the translational discourse in these different engineering education venues. Follow-on work by ourselves or other researchers could also involve applying the procedure to other journals in engineering, in order to understand similarities and differences. Future work on the procedure could also include efforts to identify and operationalize new rhetorical strategies.}

\section{Conclusion}

The work in this paper has been motivated by the idea that translational work, or the work of connecting research to action, has been gaining attention and, thus, that understanding and being able to engage in translational work is an important issue for emerging scholars. In the previous sections, we have offered and illustrated a procedure to support one aspect of translational work - reading published research articles for stated and potential implications for action. In the closing sections of the paper, we focused on how the procedure could be used by emerging scholars and also by the engineering education community as a whole. Translational work is a significant part of efforts to transform engineering education, and the work in this paper represents a contribution in that area. 


\section{References}

1. Smith, Karl. (2011). Plenary address. 2011 ASEE Annual Conference and Exposition, Vancouver, BC, June 26-29, 2011.

2. Bazerman, C. (1988). Shaping Written Knowledge: The Genre and Activity of the Experimental Article in Science. Madison, WI: University of Wisconsin Press.

3. Swales, J. M. (1990). Genre Analysis: English in academic and research settings. Cambridge, MA: Cambridge University Press.

4. Pho, Phuong Dzung. (2008). Research article abstracts in applied linguistics and educational technology: a study of linguistic realizations of rhetorical structure and authorial stance. Discourse Studies 10 (2), 231250.

5. Samraj, B. (2002). Introductions in research articles: variations across disciplines. English for Specific Purposes 21: 1-17.

6. Swales, John, and Hazem Najjar. (1987). The writing of research article introductions. Written Communication 4(2), 175-91.

7. Hopkins, Andy, and Tony Dudley-Evans. (1988). A genre-based investigation of the discussion sections in articles and dissertations. English for Specific Purposes 7(2), 113-21.

8. Peacock, M. (2002). Communicative moves in the discussion section of research articles. System, 30(4), 479-497.

9. Bartunek, Jean M., and Sara L. Rynes. (2010). The construction and contributions of "Implications for Practice": What's in them and what might they offer? Academy of Management Learning \& Education 9 , no. 1: 100-117.

10. Ohland, M. W., Brawner, C. E., Camacho, M. M., Layton, R. A., Long, R. A., Lord, S. M., \& Wasburn, M. H. (2011). Race, Gender, and Measures of Success in Engineering Education. Journal Of Engineering Education, 100(2), 225-252.

11. Taraban, R. (2011). Information Fluency Growth Through Engineering Curricula: Analysis of Students' Text-Processing Skills and Beliefs. Journal Of Engineering Education, 100(2), 397-416.

12. Yadav, A., Subedi, D., Lundeberg, M. A., \& Bunting, C. F. (2011). Problem-based Learning: Influence on Students' Learning in an Electrical Engineering Course. Journal Of Engineering Education, 100(2), 253280 .

13. Genco, N., Hölttä-Otto, K., \& Seepersad, C. (2012). An Experimental Investigation of the Innovation Capabilities of Undergraduate Engineering Students. Journal Of Engineering Education, 101(1), 60-81.

14. Tang, K. (2013). Out-of-School Media Representations of Science and Technology and their Relevance for Engineering Learning. Journal Of Engineering Education, 102(1), 51-76.

15. Nyquist, J. and Woodford, X. (2000). Re-envisioning the PhD: What concerns do we have? Downloaded from: http://depts.washington.edu/envision/resources/ConcernsBrief.pdf.

16. Journal of Translational Medicine. (2013) Downloaded from: http://www.translational-medicine.com/.

17. Tyson, C. and Ball, A. (2012). Non Satis Scire: To Know Is Not Enough. Downloaded from: http://www.aera.net/AnnualMeetingThemeHighlights/tabid/12577/Default.aspx.

18. Connor, U. (2000). Variation in rhetorical moves in grant proposals of US humanists and scientists. Text, 20(1), 1-28. 
19. Crompton, P. (1997). Hedging in academic writing: some theoretical problems. English for Specific Purposes 16(4), 271-287.

20. Hyland, K. (2002). Genre: Language, context, and literacy. Annual Review of Applied Linguistics, 22, 113135.

21. Turns, J., Paine, D., Sattler, B., \& Munoz, D. (2012). What are the implications for teaching? An analysis of how educational implications are represented in engineering education. Paper presented at the Frontiers in Education Conference (FIE), 2012.

22. Dunsmore, K., Turns, J., \& Yellin, J. M. (2011). Looking Toward the Real World: Student Conceptions of Engineering. Journal of Engineering Education, 100(2), 329-348.

23. McNair, L.D., Newswander, C., Boden, D., \& Borrego, M. (2011). Student and Faculty Interdisciplinary Identities in Self-Managed Teams. Journal Of Engineering Education, 100(2), 374-396.

24. Hong, T., Purzer, S., \& Cardella, M. E. (2011). A Psychometric Re-Evaluation of the Design, Engineering and Technology (DET) Survey. Journal Of Engineering Education, 100(4), 800-818.

25. Russell, D. R. (2007). Rethinking the articulation between business and technical communication and writing in the disciplines: Useful avenues for teaching and research. Journal of Business and Technical Communication, 21(3), 248-77.

26. Bazerman, C. (1994). Constructing Experience. Carbondale, IL: Southern Illinois University Press. 


\section{Appendix One: Dunsmore (2011) Coded Sentences}

\begin{tabular}{|c|c|c|c|c|c|}
\hline & Sentence & $\begin{array}{l}\text { Rhetorical } \\
\text { Strategy }\end{array}$ & $\begin{array}{l}\text { Action } \\
\text { Pushed }\end{array}$ & $\begin{array}{l}\text { For } \\
\text { Research? }\end{array}$ & Actor \\
\hline 22 & $\begin{array}{l}\text { Further research into the form of these continua of constructions of the } \\
\text { engineering profession could generate leverage points to foster more } \\
\text { effective student understandings of engineering practice. }\end{array}$ & Possible & $\begin{array}{l}\text { (conduct) } \\
\text { further } \\
\text { research }\end{array}$ & $\mathrm{y}$ & Not Stated \\
\hline 23 & $\begin{array}{l}\text { First, additional study of student conceptions is needed to more } \\
\text { completely characterize the nuances of their views of school, } \\
\text { engineering practice, and the relation between them. }\end{array}$ & Urged & $\begin{array}{l}\text { (conduct) } \\
\text { additional } \\
\text { study of } \ldots\end{array}$ & $\mathrm{y}$ & Not Stated \\
\hline 24 & $\begin{array}{l}\text { Studies in different engineering disciplines, comparing beginning and } \\
\text { advanced students, and other comparative studies could provide a } \\
\text { basis for generalization and application to curriculum design. }\end{array}$ & Possible & $\begin{array}{l}\text { (use other) } \\
\text { studies as a } \\
\text { basis }\end{array}$ & $\mathrm{y}$ & Not Stated \\
\hline 25 & $\begin{array}{l}\text { Second, conceptions of engineering leaders and of engineering } \\
\text { educators deserve greater attention as well, as contrasts and models for } \\
\text { comparison to student conceptions. }\end{array}$ & Urged & $\begin{array}{l}\text { (attend to) } \\
\text { conceptions of } \\
\text { engineering... }\end{array}$ & $\mathrm{y}$ & Not Stated \\
\hline 26 & $\begin{array}{l}\text { Such work is suggested by that already done in cataloguing differing } \\
\text { conceptions (expert, novice, naïve, etc.) of math and science content } \\
\text { by educators in those fields (for example, Bingolbali, Monaghan, and } \\
\text { Roper, 2006; Greenbowe and Meltzer, 2003; Parker, Krockover, } \\
\text { Laserh-Trapp, \& Eichinder, 2008). }\end{array}$ & Possible & $\begin{array}{l}\text { (conduct) } \\
\text { further } \\
\text { research }\end{array}$ & $\mathrm{y}$ & Not Stated \\
\hline 27 & Third, conceptions of engineering educators should also be studied. & Imperative & $\begin{array}{l}\text { (study) } \\
\text { conceptions of } \\
\text { engineering }\end{array}$ & $\mathrm{y}$ & Not Stated \\
\hline 31 & $\begin{array}{l}\text { Such research could build on the recent work of Pawley (2009), which } \\
\text { explores "universal narratives" of faculty such as "engineering as } \\
\text { making things." }\end{array}$ & Possible & $\begin{array}{l}\text { (conduct) } \\
\text { further } \\
\text { research }\end{array}$ & $\mathrm{y}$ & Not Stated \\
\hline 32 & $\begin{array}{l}\text { Further work could articulate the connection between the macro and } \\
\text { micro level of discourses shaping individual lived experience; for } \\
\text { example, the specific statements of students engaged in a particular } \\
\text { project as a case of the broader understanding of engineering as } \\
\text { "making things." }\end{array}$ & Possible & $\begin{array}{l}\text { (conduct) } \\
\text { further } \\
\text { research }\end{array}$ & $\mathrm{y}$ & Not Stated \\
\hline 34 & $\begin{array}{l}\text { As a starting point, this information on how students understand } \\
\text { engineering represents a resource that educators can use to think about } \\
\text { instructional activities. }\end{array}$ & Possible & $\begin{array}{l}\text { (use) this } \\
\text { information as } \\
\text { a resource }\end{array}$ & $\mathrm{n}$ & Educators \\
\hline 35 & $\begin{array}{l}\text { For example, an educator might use the information on students' ideas } \\
\text { about teamwork to anticipate how students might behave in project } \\
\text { experiences that require them to interact with people from other } \\
\text { disciplines. }\end{array}$ & Possible & $\begin{array}{l}\text { (use) this } \\
\text { information... }\end{array}$ & $\mathrm{n}$ & Educator \\
\hline 38 & $\begin{array}{l}\text { Adopting a celebratory view that embraces this complexity creates far } \\
\text { more opportunities for reaching students where they live. }\end{array}$ & Outcome & $\begin{array}{l}\text { adopt a } \\
\text { celebratory } \\
\text { view }\end{array}$ & $\mathrm{n}$ & Not Stated \\
\hline 39 & $\begin{array}{l}\text { Knowing the landscape of their constructions enables educators to } \\
\text { create multiple approaches to the integrated constructions we hope to } \\
\text { foster. }\end{array}$ & Outcome & $\begin{array}{l}\text { (know) the } \\
\text { landscape of } \\
\text { constructions }\end{array}$ & $\mathrm{n}$ & Educators \\
\hline 40 & $\begin{array}{l}\text { Making differences in conceptions more transparent creates a basis for } \\
\text { the reflection, discussion, and even debate that would enable students } \\
\text { to work from their present construction-whatever that is-toward } \\
\text { others and to evaluate the efficacy of their own and other conceptions. }\end{array}$ & Outcome & $\begin{array}{l}\text { (make) } \\
\text { differences } \\
\text { more } \\
\text { transparent... }\end{array}$ & $\mathrm{n}$ & Not Stated \\
\hline 41 & $\begin{array}{l}\text { In this way, they would also come to appreciate the complexity of } \\
\text { conceptions and how our construction of a field of action may limit or } \\
\text { expand our options for action. }\end{array}$ & Outcome & $\begin{array}{l}\text { (make) } \\
\text { differences } \\
\text { more }\end{array}$ & $\mathrm{n}$ & $\begin{array}{l}\text { Refers to } \\
\text { previous } \\
\text { sentence }\end{array}$ \\
\hline
\end{tabular}




\begin{tabular}{|c|c|c|c|c|c|}
\hline & & & transparent & & \\
\hline 43 & $\begin{array}{l}\text { Creating a portfolio, even the simple one from which this study data } \\
\text { was drawn, provides an opportunity for reflection and articulation of } \\
\text { these issues. }\end{array}$ & Outcome & $\begin{array}{l}\text { (create) } \\
\text { portfolio }\end{array}$ & $\mathrm{n}$ & Not Stated \\
\hline 44 & $\begin{array}{l}\text { Having students articulate their ideas creates a referent that educators } \\
\text { can use to reach students more effectively, design course experiences } \\
\text { that take student constructions into account more fully, and engage } \\
\text { students in a conversation with the profession they seek to join. }\end{array}$ & Outcome & $\begin{array}{l}\text { (have) } \\
\text { students } \\
\text { articulate } \\
\text { ideas }\end{array}$ & $\mathrm{n}$ & Not Stated \\
\hline 50 & $\begin{array}{l}\text { The process by which constructions develop must always be taken into } \\
\text { account. }\end{array}$ & Imperative & $\begin{array}{l}\text { (consider) the } \\
\text { process }\end{array}$ & $\mathrm{n}$ & Not Stated \\
\hline 51 & $\begin{array}{l}\text { Thus, another implication is that we should consider how students } \\
\text { have developed such ideas in the first place. }\end{array}$ & Imperative & $\begin{array}{l}\text { (consider) } \\
\text { how students } \\
\text { developed... }\end{array}$ & $\mathrm{n}$ & $\mathrm{We}$ \\
\hline 54 & $\begin{array}{l}\text { A more sophisticated understanding of the context of student } \\
\text { conceptions could lead to more sophisticated approaches to fostering } \\
\text { student conceptions. }\end{array}$ & Outcome & $\begin{array}{l}\text { (acquiring) a } \\
\text { more } \\
\text { sophisticated } \\
\text { understanding } \\
\ldots\end{array}$ & $\mathrm{n}$ & Not Stated \\
\hline 55 & $\begin{array}{l}\text { We suggest investigating educator and practitioner contributions, but } \\
\text { other contributions also merit attention. }\end{array}$ & Urged & $\begin{array}{l}\text { (investigate) } \\
\text { educator and } \\
\text { practitioner... } \\
\text { and other... }\end{array}$ & $\mathrm{n}$ & Not Stated \\
\hline 60 & $\begin{array}{l}\text { The present study indicates that portfolios can advance this teaching } \\
\text { objective. }\end{array}$ & Outcome & $\begin{array}{l}\text { (use) } \\
\text { portfolios }\end{array}$ & $\mathrm{n}$ & Not Stated \\
\hline 61 & $\begin{array}{l}\text { This paper argues that, in addition to providing a means of assessing } \\
\text { knowledge, teaching skills, and fostering social cognitions, portfolios } \\
\text { are also an important source of information for educators about social } \\
\text { cognitions students hold. }\end{array}$ & Urged & $\begin{array}{l}\text { (use) } \\
\text { portfolios as a } \\
\text { source }\end{array}$ & $\mathrm{n}$ & Not Stated \\
\hline 62 & $\begin{array}{l}\text { This paper presents an argument for the relevance of student } \\
\text { conceptions of the nature of engineering practice and for the value of } \\
\text { portfolio content as direct evidence of these conceptions. }\end{array}$ & Urged & $\begin{array}{l}\text { (use portfolios } \\
\text { as evidence of } \\
\text { conceptions) }\end{array}$ & $\mathrm{n}$ & Not Stated \\
\hline
\end{tabular}




\section{Appendix Two: McNair (2011) Coded Sentences}

\begin{tabular}{|c|c|c|c|c|c|}
\hline & Sentence & $\begin{array}{l}\text { Rhetorical } \\
\text { Strategy }\end{array}$ & $\begin{array}{l}\text { Action } \\
\text { Pushed }\end{array}$ & $\begin{array}{l}\text { For } \\
\text { Research? }\end{array}$ & Actor \\
\hline 12 & $\begin{array}{l}\text { If faculty members model interdisciplinarity in the role of their } \\
\text { institutional identities as instructors, practitioners, and researchers, } \\
\text { then students may see and experience such practices as possible in } \\
\text { their own professional roles. }\end{array}$ & Outcome & $\begin{array}{l}\text { model } \\
\text { interdisciplina } \\
\text { rity... }\end{array}$ & $\mathrm{n}$ & $\begin{array}{l}\text { Faculty } \\
\text { members }\end{array}$ \\
\hline 13 & $\begin{array}{l}\text { If the faculty model is a narrow discipline based institutional identity, } \\
\text { students must find other sources to draw from in forming } \\
\text { interdisciplinary professional roles. }\end{array}$ & Outcome & $\begin{array}{l}\text { model a } \\
\text { narrow } \\
\text { discipline... }\end{array}$ & $\mathrm{n}$ & Faculty \\
\hline 18 & $\begin{array}{l}\text { As instructors, faculty members can model institutional identities of } \\
\text { disciplinary expertise and interdisciplinarity, demonstrate valuing of } \\
\text { perspectives across disciplines, and provide scaffolding while } \\
\text { encouraging students to self-manage in teams. }\end{array}$ & Possible & $\begin{array}{l}\text { model } \\
\text { identities }\end{array}$ & $\mathrm{n}$ & $\begin{array}{l}\text { Faculty } \\
\text { members as } \\
\text { instructors }\end{array}$ \\
\hline 24 & $\begin{array}{l}\text { In academic settings, some degree of instructor scaffolding is } \\
\text { necessary and should ideally take the form of not only added structure } \\
\text { but also instructor modelling of interdisciplinary characteristics such } \\
\text { as valuing other disciplines and integrating disciplinary expertise. }\end{array}$ & Urged & $\begin{array}{l}\text { (provide) } \\
\text { scaffolding }\end{array}$ & $\mathrm{n}$ & Instructor \\
\hline 27 & $\begin{array}{l}\text { Given that several issues face faculty and students who form } \\
\text { interdisciplinary teams, we recommend further investigation of a } \\
\text { combined approach that supports a) instructor modeling of possible } \\
\text { institutional identities of interdisciplinarity and b) an affinity based, } \\
\text { self-managed work team pedagogy that facilitates shared } \\
\text { interdisciplinary team experiences. }\end{array}$ & Urged & $\begin{array}{l}\text { (conduct) } \\
\text { future } \\
\text { research }\end{array}$ & $\mathrm{y}$ & Not Stated \\
\hline 29 & $\begin{array}{l}\text { Conflicts are natural in team development, and instructors need to } \\
\text { emphasize to students that they should expect conflict and negotiate } \\
\text { through it to an effective outcome (Tuckman, 1965). }\end{array}$ & Urged & $\begin{array}{l}\text { emphasize to } \\
\text { students }\end{array}$ & $\mathrm{n}$ & Instructors \\
\hline 35 & $\begin{array}{l}\text { Scaffolding is necessary to help students transition from well-defined } \\
\text { institutional identities and expectations to self-managed project work. }\end{array}$ & Urged & $\begin{array}{l}\text { (provide) } \\
\text { scaffolding }\end{array}$ & $\mathrm{n}$ & Not Stated \\
\hline 36 & $\begin{array}{l}\text { For example, defining their own objectives for an interdisciplinary } \\
\text { semester-long project is a novel experience for most undergraduates, } \\
\text { and instructors should provide some scaffolding, e.g., by clarifying the } \\
\text { basis for course grading, instituting progress checkpoints, or adding } \\
\text { other structural elements to the course. }\end{array}$ & Imperative & $\begin{array}{l}\text { provide some } \\
\text { scaffolding }\end{array}$ & $\mathrm{n}$ & Instructors \\
\hline 38 & $\begin{array}{l}\text { However, too much structure might negatively impact interdisciplinary } \\
\text { team-building based on affinity identity. }\end{array}$ & Outcome & $\begin{array}{l}\text { (provide) too } \\
\text { much } \\
\text { structure }\end{array}$ & $\mathrm{n}$ & Not Stated \\
\hline 39 & $\begin{array}{l}\text { Faculty could try to reduce uncertainty and ambiguity through other } \\
\text { means than prescribing specific outcomes or approaches. }\end{array}$ & Possible & $\begin{array}{l}\text { reduce } \\
\text { uncertainty } \\
\text { and ambiguity }\end{array}$ & $\mathrm{n}$ & Faculty \\
\hline 40 & $\begin{array}{l}\text { For example, they might add an activity that promotes valuing other } \\
\text { disciplinary perspectives by encouraging team members to create } \\
\text { common understandings of quality. }\end{array}$ & Possible & add activity & $\mathrm{n}$ & $\begin{array}{l}\text { Refers to } \\
\text { previous } \\
\text { sentence }\end{array}$ \\
\hline 51 & $\begin{array}{l}\text { It is possible, then, that interdisciplinary teaming that promotes } \\
\text { discourse, especially explanations across disciplines, could help } \\
\text { students develop their disciplinary expertise. }\end{array}$ & Outcome & $\begin{array}{l}\text { (working in) } \\
\text { interdisciplina } \\
\text { ry teams... }\end{array}$ & $\mathrm{n}$ & Not Stated \\
\hline 54 & $\begin{array}{l}\text { However, if faculty and students find ways to engage in } \\
\text { interdisciplinary experiences within this space, they can use those } \\
\text { experiences to create affinity identities that could also inform their } \\
\text { professional roles. }\end{array}$ & Outcome & $\begin{array}{l}\text { find ways to } \\
\text { engage... }\end{array}$ & $\mathrm{n}$ & $\begin{array}{l}\text { Faculty and } \\
\text { students }\end{array}$ \\
\hline 56 & $\begin{array}{l}\text { Clearly, there is more work to be done in understanding how best to } \\
\text { cultivate interdisciplinary teaming skills to prepare engineering } \\
\text { students for a globalized world. }\end{array}$ & Urged & $\begin{array}{l}\text { (doing) more } \\
\text { work }\end{array}$ & $\mathrm{y}$ & Not Stated \\
\hline
\end{tabular}


Appendix Three: Hong (2011) Coded Sentences

\begin{tabular}{|c|c|c|c|c|c|}
\hline & Sentence & $\begin{array}{l}\text { Rhetorical } \\
\text { Strategy }\end{array}$ & $\begin{array}{l}\text { Action } \\
\text { Pushed }\end{array}$ & $\begin{array}{l}\text { For } \\
\text { Research? }\end{array}$ & Actor \\
\hline 19 & $\begin{array}{l}\text { We recommend that a revised version of the DET instrument include a } \\
\text { "neutral" category in its scale to increase its psychometric quality and } \\
\text { suggest that additional analyses are conducted with a larger sample } \\
\text { size. }\end{array}$ & Urged & $\begin{array}{l}\text { include a } \\
\text { "neutral" } \\
\text { category in } \\
\text { revised } \\
\text { version of the } \\
\text { DET } \\
\text { instrument }\end{array}$ & $\mathrm{y}$ & Not Stated \\
\hline 22 & $\begin{array}{l}\text { This does not mean, however, that these four items should be removed } \\
\text { from the DET instrument right away. }\end{array}$ & Imperative & $\begin{array}{l}\text { [don't] remove } \\
\text { these four } \\
\text { items from the } \\
\text { DET } \\
\text { instrument }\end{array}$ & $\mathrm{y}$ & Not Stated \\
\hline 23 & $\begin{array}{l}\text { Although the statistical evidence from item analysis supports doing so, } \\
\text { it is strongly recommended to carefully examine the items again and } \\
\text { identify possible reasons why low item-total correlations were } \\
\text { observed. }\end{array}$ & Urged & $\begin{array}{l}\text { examine the } \\
\text { items again } \\
\text { and identify } \\
\text { possible } \\
\text { reasons why } \\
\text { low item-total } \\
\text { correlations } \\
\text { were observed }\end{array}$ & $\mathrm{y}$ & Not Stated \\
\hline 28 & $\begin{array}{l}\text { Deleting items may lead to an insufficient number of items to make up } \\
\text { an overall reliable scale, because the fewer the number of items, the } \\
\text { less reliable the overall scale would be. }\end{array}$ & Outcome & (delete) items & $\mathrm{y}$ & Not Stated \\
\hline 30 & $\begin{array}{l}\text { For this issue, what we recommend are: (1) comparing the content of } \\
\text { the item with empirical findings from previous research (for surveys } \\
\text { such as the DET), or with the instructional objectives (for general } \\
\text { achievement tests) again to improve the face and content validity, (2) } \\
\text { consulting with the content experts to collect suggestions on revising } \\
\text { the problematic items, and (3) collecting more data with the revised } \\
\text { version of the DET to cross-validate the item analysis results. }\end{array}$ & Urged & $\begin{array}{l}\text { (compare) the } \\
\text { content... (con } \\
\text { sult) with the } \\
\text { content } \\
\text { experts... (coll } \\
\text { ect) more data }\end{array}$ & $\mathrm{y}$ & Not Stated \\
\hline 33 & $\begin{array}{l}\text { It would be interesting to analyze what possibly caused this situation } \\
\text { through follow-up studies (e.g., interviews). }\end{array}$ & Possible & $\begin{array}{l}\text { analyze what } \\
\text { possibly } \\
\text { caused this } \\
\text { situation } \\
\text { through } \\
\text { follow-up } \\
\text { studies }\end{array}$ & $\mathrm{y}$ & Not Stated \\
\hline 36 & $\begin{array}{l}\text { Although we do not recommend deleting any items merely based on } \\
\text { low performance, both the statistical evidence and content experts' } \\
\text { opinions supported that the overall factor structure would be better off } \\
\text { without this item. }\end{array}$ & Urged & $\begin{array}{l}\text { (delete one } \\
\text { item...most } \\
\text { people feel } \\
\text { that male } \\
\text { students can } \\
\text { do well in } \\
\text { DET) }\end{array}$ & $\mathrm{y}$ & Not Stated \\
\hline 37 & $\begin{array}{l}\text { Consequently, this item was not recommended to be contained in the } \\
\text { DET instrument in future administration and research. }\end{array}$ & Urged & $\begin{array}{l}\text { (do not } \\
\text { contain) this } \\
\text { item in the } \\
\text { DET } \\
\text { instrument }\end{array}$ & $\mathrm{y}$ & Not Stated \\
\hline 42 & $\begin{array}{l}\text { Measuring teachers' perceptions regarding the importance of DET, } \\
\text { perceptions of engineers, as well as their perceived barriers in teaching } \\
\text { DET are necessary to support evaluation of teacher professional } \\
\text { development programs. }\end{array}$ & Urged & $\begin{array}{l}\text { (measure) } \\
\text { teachers' } \\
\text { perceptions } \\
\text { regarding the } \\
\text { important of } \\
\text { DET... }\end{array}$ & $\mathrm{y}$ & Not Stated \\
\hline
\end{tabular}




\begin{tabular}{|c|c|c|c|c|c|}
\hline 43 & $\begin{array}{l}\text { Such data can help determine why some teachers are successful in } \\
\text { their implementation efforts. }\end{array}$ & Outcome & [collect] data & $\mathrm{y}$ & Not Stated \\
\hline 52 & $\begin{array}{l}\text { For instance, a well-designed survey format, clear instructions, concise } \\
\text { item content without ambiguity, a comfortable survey administration } \\
\text { environment, post-survey appreciation, and feedback regarding the use } \\
\text { of data collected, etc., can all help respondents become more interested } \\
\text { and involved. }\end{array}$ & Outcome & $\begin{array}{l}\text { help } \\
\text { respondents } \\
\text { become more } \\
\text { interested and } \\
\text { involved }\end{array}$ & $y$ & Not Stated \\
\hline 56 & $\begin{array}{l}\text { All these findings provide researchers with a fairly strong empirical } \\
\text { basis for the use of the refined DET. }\end{array}$ & Urged & (use) DET & $y$ & Researchers \\
\hline 57 & $\begin{array}{l}\text { Researchers need to be careful when using or adapting a previously } \\
\text { designed instrument for their own research, because when samples are } \\
\text { different, it is possible that the factor structure of the same instrument } \\
\text { needs to be adjusted. }\end{array}$ & Urged & $\begin{array}{l}\text { be careful } \\
\text { when using or } \\
\text { adapting a } \\
\text { previously } \\
\text { designed } \\
\text { instrument }\end{array}$ & $\mathrm{y}$ & Researchers \\
\hline 58 & $\begin{array}{l}\text { To cross-validate or "re-visit" an established instrument with moderate } \\
\text { psychometric evidence like the DET, we suggest researchers start with } \\
\text { a CFA to test the fit of the factor structure with the current sample. }\end{array}$ & Urged & $\begin{array}{l}\text { start with a } \\
\text { CFA to test } \\
\text { the fit }\end{array}$ & $y$ & Researchers \\
\hline 59 & $\begin{array}{l}\text { If the factor structure fits the current sample, then there is no need to } \\
\text { proceed any further because the factor structure is proved valid using a } \\
\text { different sample. }\end{array}$ & Urged & $\begin{array}{l}{[\text { don't] }} \\
\text { proceed any } \\
\text { further }\end{array}$ & $\mathrm{y}$ & Not Stated \\
\hline 60 & $\begin{array}{l}\text { However, if the factor structure does not fit the sample then it is } \\
\text { necessary to go back and use EFA to explore whether the original } \\
\text { factor structure truly represents or explains the inter-correlations } \\
\text { among the factors. }\end{array}$ & Outcome & $\begin{array}{l}\text { go back and } \\
\text { use EFA to } \\
\text { explore... }\end{array}$ & $\mathrm{y}$ & Not Stated \\
\hline 61 & $\begin{array}{l}\text { If the objective is to validate a newly-designed instrument, we suggest } \\
\text { using Messick (1995)'s guidelines on instrument design and } \\
\text { validation. }\end{array}$ & Urged & $\begin{array}{l}\text { (use) } \\
\text { Messick's } \\
\text { guidelines on } \\
\text { instrument } \\
\text { design and } \\
\text { validation }\end{array}$ & $\mathrm{y}$ & Not Stated \\
\hline 64 & $\begin{array}{l}\text { Collaborations among researchers can help overcome such challenges } \\
\text { when evaluating and re-evaluating survey tools. }\end{array}$ & Outcome & $\begin{array}{l}\text { (collaborate) } \\
\text { with } \\
\text { researchers }\end{array}$ & $\mathrm{y}$ & Not Stated \\
\hline 65 & $\begin{array}{l}\text { In addition to studies with increased sample size, future research } \\
\text { should examine the revised factor structure for middle school and high } \\
\text { school teachers as well as with teachers in different cultural contexts } \\
\text { and countries. }\end{array}$ & Imperative & $\begin{array}{l}\text { examine the } \\
\text { revised factor } \\
\text { structure }\end{array}$ & $\mathrm{y}$ & Not Stated \\
\hline
\end{tabular}

